\title{
ペルオキシゾーム増殖剤応答性受容体（PPAR）の発現量が調節可能な ヒト肝癌由来細胞株の樹立とその応用
}

\author{
橘 敬 祐
}

\section{Application of the Human Hepatoblastoma Cell Lines Inducibly Expressing Peroxisome Proliferator-activated Receptors (PPARs)}

\author{
Keisuke TACHIBANA \\ Graduate School of Pharmaceutical Sciences, Osaka University, 1-6 Yamadaoka, Suita City 565-0871, Japan
}

(Received April 25, 2007)

\begin{abstract}
Peroxisome proliferator-activated receptors (PPARs) are ligand-activated transcription factors and commonly play an important role in the regulation of lipid homeostasis. Although three PPAR subtypes, $\alpha, \delta$ and $\gamma$ show a relatively close amino acid sequence homology, the functions of each PPAR are distinct. For example, PPAR $\alpha$ and PPAR $\delta$ induce lipid oxidation, while PPAR $\gamma$ activates lipid storage and adipogenesis. To analyze the detail functions of human PPARs, we previously established tetracycline-regulated human hepatoblastoma cell lines that can be induced to express each human PPAR subtype. The expression of each PPAR subtype in established cell line was tightly controlled by the concentration of doxycycline. DNA microarray analyses using these cell lines were performed with or without adding ligand and provided the important information on the PPAR target genes. Furthermore, we analyzed the 5 '-flanking region of the human adipose differentiation-related protein (adrp) gene that responded to all subtypes of PPARs, and determined the functional PPRE of the human adrp gene. Here we discuss the usefulness of these cell lines.
\end{abstract}

Key words_— peroxisome proliferator-activated receptor; Tet-system; gene expression analysis; adipose differentiation-related protein

\section{1. はじめに}

ペルオキシゾーム増殖剤応答性受容体（peroxisome proliferator-activated receptor; PPAR）は,リ ガンド依存的に転写を制御する核内受容体の 1 つで あり，哺乳動物においては $\operatorname{PPAR} \alpha, \delta, \gamma$ 3 種類 のサブタイプが存在する. ${ }^{1)} \operatorname{PPAR} \alpha$ は主として肝 臓，腎臓，心臓，小腸などに発現しており，脂肪酸 $\beta$ 酸化系の酵素などの発現を誘導し, 脂質代謝の調 節において重要な役割を担っている.2）チアゾリジ ン系薬剤をリガンドとする PPAR $\gamma$ は, 脂肪組織, マクロファージなどに発現しており, 脂肪細胞の分 化, 脂質の取り込みや抗炎症作用などを発揮す る. ${ }^{3)}$ また, 脂肪肝を伴うような過栄養状態に生体 がおかれると肝臓での発現が誘導されるが, その機

大阪大学大学院薬学研究科蛋白情報解析学分野（干565 -0871 吹田市山田丘 1-6)

e-mail: nya@phs.osaka-u.ac.jp

*本総説は, 平成 18 年度日本薬学会近畿支部奨励賞の

受賞を記念して記述したものである。
能に関しては不明な点が多く残されている. ${ }^{4,5}$ $\operatorname{PPAR} \delta$ は組織特異的な発現がみられず普遍的に発 現しているが，骨格筋や脂肪組織において脂肪酸代 謝の亢進やエネルギーの消費を誘導すること, ${ }^{6)}$ ま た，皮膚の上皮組織において分化促進や創傷治癒に 関与すること7)などが報告されている.

このように, PPAR の機能は徐々に明らかにさ れつつあるが, その機能はヒトとげっ歯類で異なる ことも報告されている，例えば， $\operatorname{PPAR} \alpha$ のリガ ドであるフィブラート系薬剂は，ヒトにおいて脂質 代謝改善作用を発揮するが，げっ歯類においてはぺ ルオキシゾームの増殖や肝癌を誘発する. しかし, これら種差が生じる機構については明らかにされて いない. ${ }^{8)}$

このような観点から筆者らは，ヒトPPAR の機 能を明らかにする目的で，テトラサイクリン誘導シ ステムを用いた PPAR の発現を制御できるヒト肝 癌由来細胞株を樹立し, トランスクリプトーム解析 を行った．本稿では，筆者らが得た研究成果を交え， 
PPAR の機能について概説したい.

\section{PPAR の構造と機能}

ヒト PPAR には $\alpha, \delta, \gamma$ の 種類のサブタイプが 存在し, さらに, PPAR $\gamma$ には $\gamma 1$ と $\gamma 2$ のアイソフ オームが存在する（Fig. 1(A))。PPAR は他の核内 受容体と同様に， $\mathrm{N}$ 末端側よりリガンド非依存的 な転写活性化領域である A/B 領域, DNA 結合領 域である C 領域, ヒンジ領域である D 領域, リガ ンド結合部位を含むリガンド依存的な転写活性化を 司る $\mathrm{E} / \mathrm{F}$ 領域よりなる. 1) PPAR は 9-cis-レチノイ ン酸をリガンドとする核内受容体 retinoid X receptor $(\mathrm{RXR})$ とへテロ 2 量体を形成することにより，

基本モチーフの配列（5'-AGGTCA-3'） が 1 塩基隔 てて同じ方向に並んだダイレクトリピート 1 （DR1）の配列を有する PPAR 応答配列（PPAR response element; PPRE) に結合する.この DNA との結合に重要な C 領域は, PPAR サブタイプ間 で $80 \%$ 以上の高い相同性を有している。この領域 には 2 つの $\mathrm{Zn}$ フィンガー構造があり， $\mathrm{N}$ 末端側の $\mathrm{Zn}$ フィンガー構造に存在する 5 アミノ酸残基から なる $\mathrm{P}$ ボックスが，結合する基本モチーフの配列
を認識する。また， $\mathrm{C}$ 末端側の $\mathrm{Zn}$ フィンガー構造 には D ボックスがあり，モチーフ間の距離を認識 すると考えられている（Fig. 1 (A)). ${ }^{9)}$ 一方， PPAR のリガンド結合領域は他の核内受容体と比 較し，非常に大きなリガンド結合ポケットを有して いることが構造解析の結果より明らかになってい る.10)このことは, 多様な化合物が PPAR のリガ ンドになり得ることを示唆している.

これら PPAR の内因性のリガンドとしては，長 鎖脂肪酸やエイコサノイドがすべてのサブタイプの アゴニストとして働くほか，ロイコトリエン B4 が $\operatorname{PPAR} \alpha$ の，15-deoxy- $\Delta^{12,14}$-prostaglandin $\mathrm{J} 2$ などの 脂肪酸誘導体が PPAR $\gamma$ のアゴニストとして報告さ れている. ${ }^{1)}$ 一方, 合成リガンドとしては PPAR $\alpha$ のリガンドであるフィブラート系薬剤が抗高脂血症 薬として，PPAR $\gamma$ のリガンドであるチアゾリジン 系薬剂が抗糖尿病薬として用いられている.1 ${ }^{1}$ また, $\operatorname{PPAR} \delta$ のリガンドは，骨格筋や脂肪組織において エネルギー消費を克進し，体重増加抑制及びインス リン抵抗性改善効果を示すことから，抗肥満薬にな り得ることが示唆されている. ${ }^{6,11)}$

(A)
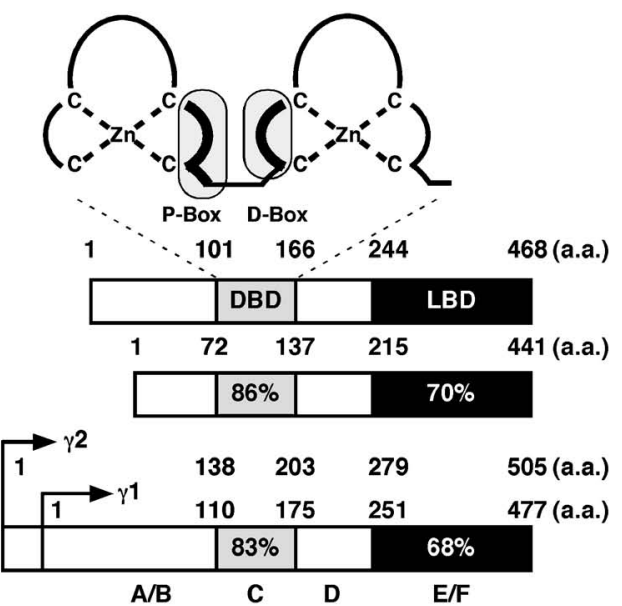

(B)

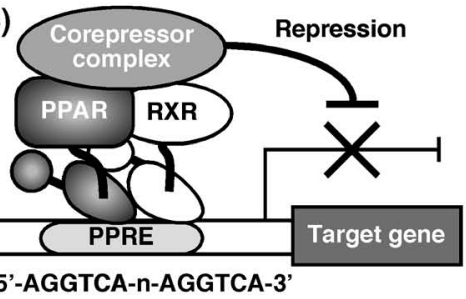

A/B $\quad$ C $\quad$ D $\quad E / F$
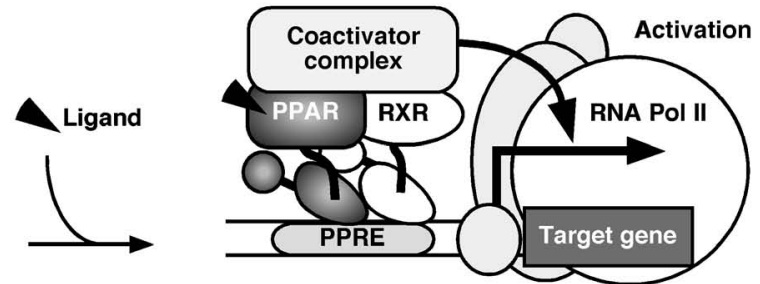

Fig. 1. The General Features of Human PPARs

(A) Structure and functional domain of human PPARs. A/B, C, D and E/F indicate N-terminal A/B domain containing a ligand-independent activation function 1, DNA-binding domain (DBD), hinge region and C-terminal ligand-binding domain (LBD), respectively. (B) PPAR/RXR heterodimers bind to a PPRE located in the promoter of target genes through the DBD. Unliganded PPAR associates with the corepressor complex. In the presence of ligand, the ligand-bound LBD associates with the coactivator complex. 
PPAR はこれらリガンドと結合することで， ヒ ストンアセチル化酵素活性を有するコアクチベー ターなどと相互作用し標的遺伝子の転写を活性化す る。一方，リガンドと結合していない状態では，コ リプレッサーと相互作用することで転写活性を抑制 している（Fig. 1(B)). 12,13) また，PPARにはリガ ンド非依存的な転写制御機構も存在する。様々な刺 激を受けることで PPAR はリン酸化などの翻訳後 修飾を受け，その転写活性化能が調節される. ${ }^{14,15)}$ このように，PPARによる転写は様々な因子が複 雑に絡夕合って制御されている.

3. テトラサイクリン誘導システムを用いたヒト PPAR を発現する細胞株の樹立

前述したように，PPAR はリガンド依存的な転 写因子であることから，標的遺伝子産物群の発現を 介してその機能を発揮する。したがって，ヒトにお ける PPAR の機能を解析するためには，ヒトの細 胞における PPAR の標的遺伝子を明らかにするこ とが重要である.

そこで筆者らは，テトラサイクリン誘導システム （Tet-Off システム）を用いて 4 種類の PPAR サブタ イプの発現を制御できるヒト肝癌由来細胞株を樹立 した (HepG2-tet-off-hPPAR $\alpha, \operatorname{hPPAR} \delta, \operatorname{hPPAR} \gamma 1$, hPPAR $\gamma 2) .16)$ これら細胞株におけるPPAR の発現 量は，テトラサイクリン（又は，その誘導体である ドキシサイクリン (Dox)) を培地から除去するこ とで上昇し，その発現量は Dox 濃度依存的であっ た（Fig. 2)。また，Dox を除去し PPAR を発現さ せたのちにリガンドで処理することにより，標的遺 伝子である 3-hydroxy-3-methylglutaryl-CoA synthase 2 (HMGCS2)の発現が誘導された (Fig. 3). 以上のことから，これら PPAR 発現細胞株は， Dox を除去することにより機能するPPAR を発現 することが確認できた。

\section{PPAR 発現細胞株を用いた網羅的遺伝子発現} 解析

次に，この細胞株を用いてトランスクリプトーム 解析を行うことにより，PPAR に応答する遺伝子 の網羅的解析を試みた. ${ }^{16)}$ Dox 除去後の PPAR が 発現している細胞に，それぞれのリガンド，若しく は，コントロールとして DMSO を添加して 24 時 間培養したものと，Dox を除去せずにPPAR を発 現させていない細胞を用いて各遺伝子の発現変動を
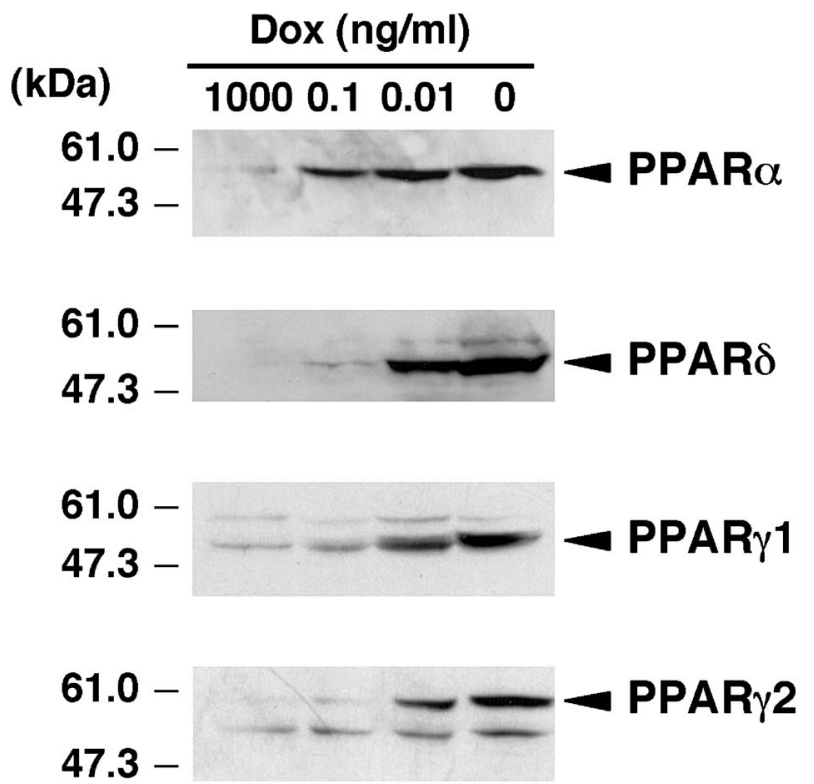

Fig. 2. Induction of the Expression of PPAR by Doxycycline in Established Cell Lines

Nuclear extracts from each cell line cultured in the presence of the indicated amounts of Dox for 5 days were subjected to SDS-PAGE and immunoblots were performed with anti-PPAR $\alpha$, anti-PPAR $\delta$ or anti-PPAR $\gamma$.

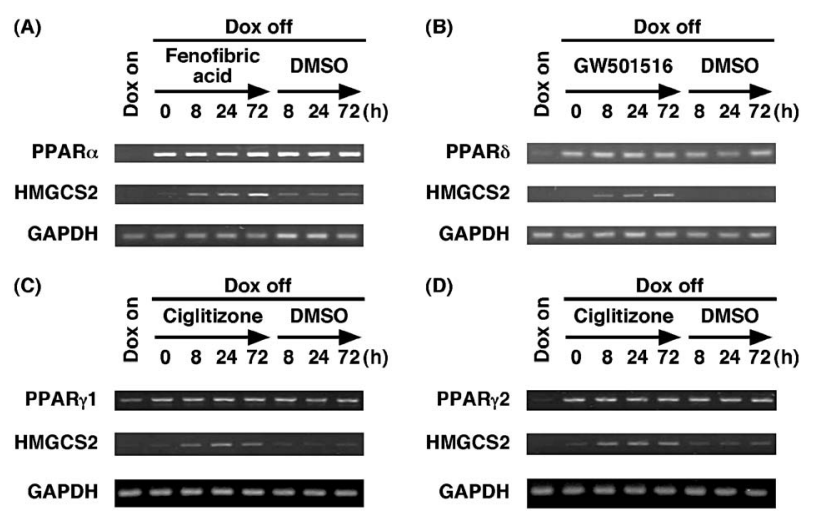

Fig. 3. HMGCS2 mRNA Expressions were Modulated by PPARs in Tet-Regulated HepG2 Cells

(A, B, C and D) HepG2-tet-off-hPPAR cells were treated with DMSO or ligands $(100 \mu \mathrm{M}$ fenofibric acid for PPAR $\alpha$ (A), $100 \mathrm{nM}$ GW501516 for $\operatorname{PPAR} \delta(\mathrm{B})$ or $10 \mu \mathrm{M}$ ciglitizone for PPAR $\gamma(\mathrm{C}$ and D) ) for $0,8,24$ or $72 \mathrm{~h}$ in the absence of Dox. Messenger RNA levels of human HMGCS2 were measured by RT-PCR.

解析した．その結果，リガンドに応答して脂肪酸代 謝に係わる遺伝子を始め，脂肪酸輸送，糖代謝など に係わる遺伝子の発現が上昇した（Table 1)，生体 内においては, PPAR $\alpha$ は肝臓で脂肪酸代謝を制御 しており，また，PPAR $\gamma$ は脂肪細胞の分化，脂質 の蓄積に関与している。今回の実験結果から，樹立 した細胞株においても主に PPAR $\alpha$ は脂肪酸代謝に 関する遺伝子群を誘導し，また，PPAR $\gamma$ は脂肪酸 
Table 1. Changes in mRNA Expression Levels of Metabolism-related Genes in HepG2-tet-off-hPPAR Cells by Ligands

\begin{tabular}{|c|c|c|c|c|c|c|c|c|}
\hline \multirow{3}{*}{ Gene } & \multicolumn{8}{|c|}{ Fold change } \\
\hline & \multicolumn{2}{|c|}{$\operatorname{PPAR} \alpha$} & \multicolumn{2}{|c|}{$\operatorname{PPAR} \delta$} & \multicolumn{2}{|c|}{$\operatorname{PPAR} \gamma 1$} & \multicolumn{2}{|c|}{ PPAR $\gamma 2$} \\
\hline & $\begin{array}{c}\text { DMSO } \\
\text { vs. } \\
\text { Dox }\end{array}$ & $\begin{array}{l}\text { Feno } \\
\text { vs. } \\
\text { Dox }\end{array}$ & $\begin{array}{c}\text { DMSO } \\
\text { vs. } \\
\text { Dox }\end{array}$ & $\begin{array}{l}\text { GW } \\
\text { vs. } \\
\text { Dox }\end{array}$ & $\begin{array}{c}\text { DMSO } \\
\text { vs. } \\
\text { Dox }\end{array}$ & $\begin{array}{l}\text { Cig } \\
\text { vs. } \\
\text { Dox }\end{array}$ & $\begin{array}{c}\text { DMSO } \\
\text { vs. } \\
\text { Dox }\end{array}$ & $\begin{array}{l}\text { Cig } \\
\text { vs. } \\
\text { Dox }\end{array}$ \\
\hline
\end{tabular}

Fatty acid metabolism

\begin{tabular}{|c|c|c|c|c|c|c|c|c|}
\hline Acyl-CoA synthetase long-chain family member 1 & 1.84 & 3.49 & 0.82 & 1.72 & 0.88 & 2.30 & 0.82 & 1.00 \\
\hline Carnitine palmitoyltransferase $1 \mathrm{~A}$ (liver) & 1.48 & 2.86 & 0.37 & 2.05 & 0.74 & 1.35 & 1.12 & 1.24 \\
\hline $\begin{array}{l}\text { Solute carrier family } 25 \text { (carnitine/acylcarnitine translocase), } \\
\text { member } 20\end{array}$ & 1.20 & 2.23 & 0.91 & 1.36 & 0.83 & 0.93 & 1.04 & 1.27 \\
\hline Acyl-Coenzyme A dehydrogenase, very long chain & 2.16 & 3.46 & 0.92 & 2.69 & 1.36 & 1.97 & 1.55 & 2.33 \\
\hline Acyl-Coenzyme A dehydrogenase, C-4 to C-12 straight chain & 1.62 & 2.52 & 0.64 & 2.03 & 1.24 & 1.48 & 1.40 & 1.80 \\
\hline Trifunctional protein, beta subunit & 1.74 & 2.66 & 0.95 & 1.30 & 1.17 & 1.49 & 1.14 & 1.62 \\
\hline Acetyl-Coenzyme A acyltransferase 2 & 1.58 & 1.92 & 1.06 & 1.63 & 0.89 & 1.31 & 1.18 & 2.44 \\
\hline Enoyl Coenzyme A hydratase 1, peroxisomal & 2.28 & 2.61 & 0.99 & 2.05 & 1.16 & 1.46 & 1.44 & 1.98 \\
\hline \multicolumn{9}{|l|}{ Antioxidant } \\
\hline Catalase & 1.51 & 2.36 & 0.68 & 1.45 & 1.06 & 1.54 & 1.69 & 2.59 \\
\hline \multicolumn{9}{|l|}{ Ketogenesis } \\
\hline 3-Hydroxy-3-methylglutaryl-Coenzyme A synthase 2 & 32.40 & 156.62 & 1.13 & 2.51 & 2.14 & 6.57 & 2.20 & 6.53 \\
\hline \multicolumn{9}{|l|}{ Transport/strage } \\
\hline Fatty acid binding protein 1 , liver & 1.39 & 2.08 & 0.18 & 1.33 & 2.73 & 6.52 & 3.52 & 10.44 \\
\hline Adipose differentiation-related protein & 1.96 & 3.44 & 0.22 & 2.90 & 3.33 & 6.06 & 3.40 & 5.73 \\
\hline PDZ domain containing 1 & 2.16 & 3.02 & 0.52 & 2.85 & 1.03 & 2.42 & 1.98 & 3.21 \\
\hline Lipase, hepatic & 8.34 & 10.39 & 0.72 & 2.89 & 1.08 & 2.47 & 1.64 & 3.99 \\
\hline \multicolumn{9}{|l|}{ Gluconeogenesis } \\
\hline Aquaporin 3 & 3.00 & 5.86 & 0.26 & 1.91 & 1.58 & 3.41 & 1.38 & 3.09 \\
\hline Glycerol kinase & 0.87 & 1.57 & 0.73 & 0.79 & 1.00 & 1.21 & 1.84 & 3.17 \\
\hline Phosphoenolpyruvate carboxykinase 1 (soluble) & 6.39 & 17.90 & 0.83 & 4.64 & 6.94 & 29.19 & 34.46 & 110.78 \\
\hline \multicolumn{9}{|l|}{ Metabolism } \\
\hline Angiopoietin-like protein 4 & 1.71 & 17.97 & 3.00 & 25.67 & 1.24 & 7.27 & 3.88 & 33.56 \\
\hline Heme oxygenase (decycling) 1 & 1.25 & 2.21 & 0.66 & 1.25 & 1.31 & 2.20 & 2.18 & 4.20 \\
\hline
\end{tabular}

Microarray analyses were performed on HepG2-tet-off-hPPAR cells; the cells were cultured in the presence (Dox) or absence of Dox for 5 days. In the absence of Dox, the cells were treated with ligands (100 $\mu$ m fenofibric acid for PPAR $\alpha$ (Feno), $100 \mathrm{nM}$ GW501516 for PPAR $\delta$ (GW) or $10 \mu \mathrm{M}$ ciglitizone for PPAR $\gamma$ $(\mathrm{Cig}))$ or DMSO for $24 \mathrm{~h}$. Gene expression profiles were compared between DMSO and Dox or ligands and Dox.

の取り込みや輸送に関する遺伝子群を誘導する傾向 が認められた。しかしながら，いずれのPPAR も これら遺伝子の発現を誘導した。このことから，生 体内における PPAR の特異的な機能は，主にその 組織特異的な発現パターンによって規定されている のではないかと考えられる，すなわち，組織特異的 な転写共役因子や他の転写因子の存在，リガンドの
有無，クロマチン構造などが PPAR の組織におけ る機能の違いに重要な影響を及ぼしていると思われ る. ${ }^{12,17)}$

興味深いことに, リガンドのない状態でも $\operatorname{PPAR} \alpha$ とPAR $\gamma$ は標的遺伝子の発現を誘導し た。これは，細胞内に含まれる脂肪酸やアラキドン 酸の代謝物などがリガンドとして働いている可能性 
が考えられた. ${ }^{18,19)}$ 一方で，PPAR $\delta$ はリガンドのな い状態ではいくつかの遺伝子の発現を抑制した。こ れまでに，PPAR $\delta$ はリガンドのない状態でコリプ レッサーと相互作用し，標的遺伝子の転写を抑制す ることが報告されている. ${ }^{20,211)}$ また, PPAR $\delta$ のリ ガンド結合ポケットは，PPAR $\alpha$ PPAR $\gamma$ に比較

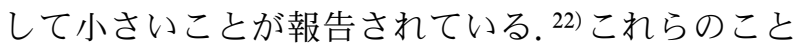
が，今回樹立した細胞株における $\operatorname{PPAR} \alpha, \gamma$ と $\operatorname{PPAR} \delta$ の転写制御の違いに現れたのかもしれな い.この点に関しては更なる研究が必要であるもの の, 本研究成果から, 今回樹立した細胞株は PPAR の転写制御機構を解析する上で，よいツー ルになると考えられる。

\section{PPARによる ADRP 遺伝子の発現制御機構}

トランスクリプトーム解析の結果, adipose differentiation-related protein (ADRP) 遺伝子の発 現がいずれのPPAR サブタイプにも応答して変化 していた（Table 1).ADRP は脂肪滴に特異的に局
在するタンパク質で，様々な細胞で発現しており,

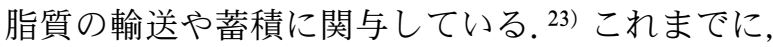
マウス ADRP プロモーターのー $2000 \mathrm{bp}$ 付近に PPRE が存在することが報告されていたが, ${ }^{24)}$ ヒト のPPREは同定されていなかった。そこで, PPAR によるヒトADRP の発現調節機構を解析し た. ${ }^{16)}$

まず，ヒト ADRP プロモーターの塩基配列をマ ウスのプロモーターと比較した結果，ヒトのプロ モーターのー2300 bp 付近に PPRE の候補配列を見 出した（Fig. 4(A))。 そこで，この領域を含むプロ モーターを用いてレポーターアッセイを行った (hADRP-4K)。同時に, PPRE と推定される領域 から上流部分を削つたプロモーター (hADRP-d1), 及び，その配列に変異を加えたプロモーター （hADRP-mut）を含むレポータープラスミドも用 いた。その結果，いずれの PPAR サブタイプもリ ガンドに応答してヒト ADRP プロモーターを活性

(A)

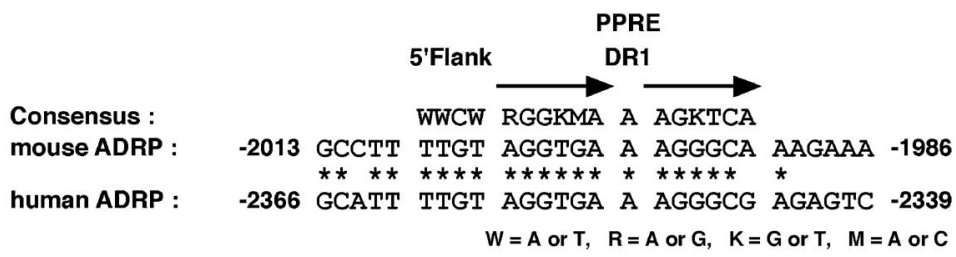

(B)

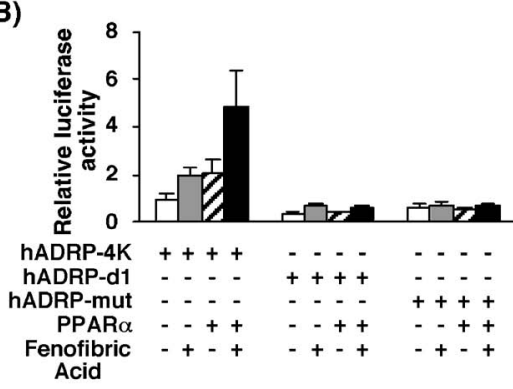

(D)

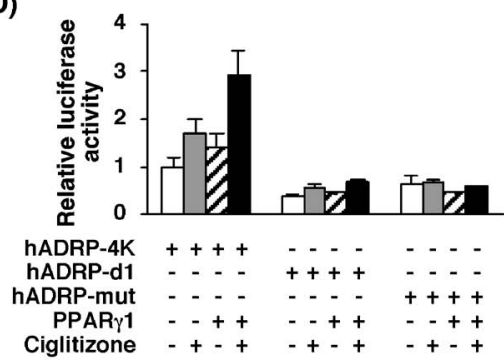

(C)

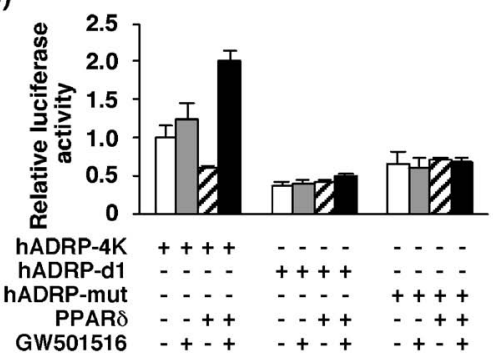

(E)

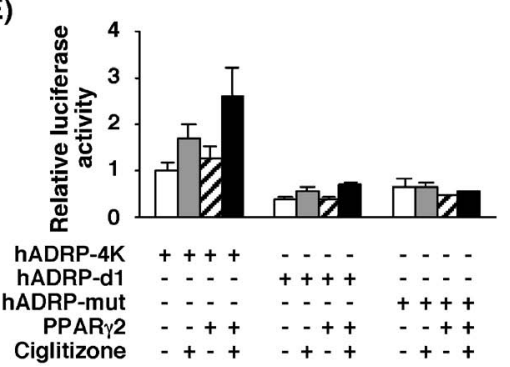

Fig. 4. PPARs Modulate Human ADRP Promoter Activity via a PPRE Located between -2361 and -2345 bp

(A) A sequence corresponding to the $-2366 /-2339$ region of the human adrp gene, was compared with a consensus PPRE and the analogous regions in the mouse adrp gene promoter $(-2013 /-1986)$. Asterisks denote conserved bases. (B, C, D and E) HepG2 cells were co-transfected with a human ADRP reporter plasmid, phRL-TK and either pcDNA3-hPPAR $\alpha$ (B), pcDNA3-hPPAR $\delta$ (C), pcDNA3-hPPAR $\gamma 1$ (D) or pcDNA3-hPPAR $\gamma 2$ (E). Transfected cells were treated with ligands (100 $\mu \mathrm{M}$ fenofibric acid (B), $100 \mathrm{nM} \mathrm{GW501516}$ (C) or $10 \mu \mathrm{M}$ ciglitizone (D and E)) for $24 \mathrm{~h}$ and the cells were used for reporter gene assays. Luciferase activities from reporter plasmids were normalized by internal Renilla luciferase activity. 
化した。また，この効果はPPRE を欠失，又は， 変異を加えた場合には認められなかった（Fig. 4 (B-E)). このことから，この領域がヒト ADRP の PPREである可能性が示唆された.

次に, PPARのこの領域への結合を調べた。ま ず，ゲルシフトアッセイを行ったところ，いずれの PPAR サブタイプも RXR $\alpha$ と 2 量体を形成してこ の領域に結合した（Fig. $5(\mathrm{~A} ）$; ここには PPAR $\alpha$ の結果のみ示す)。さらに，クロマチン免疫沈降法 により，細胞内での PPAR と $\mathrm{RXR} \alpha$ の $\mathrm{ADRP} フ ゚$ ロモーターへの結合を調べた。 その結果, 細胞内に おいても PPAR と RXR $\alpha$ の 2 量体が ADRP プロ モーターに結合していることが明らかになった (Fig. 5 (B) ; ここには PPAR $\alpha$ の結果のみ示す).

以上の結果，筆者らはヒトADRP の PPRE を同

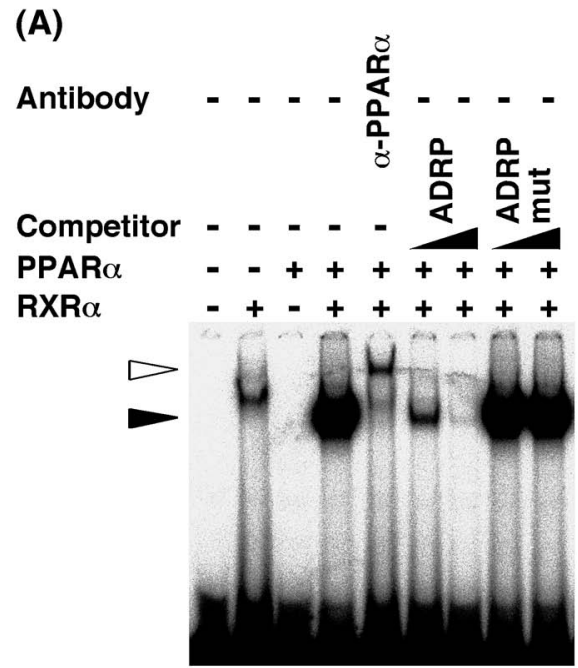

(B)

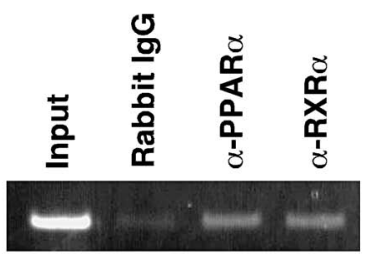

Fig. 5. PPAR $\alpha$ Binds to the PPRE in the $-2366 /-2339$ Region of the Human adrp Gene

(A) EMSA was performed with the ${ }^{32} \mathrm{P}$-labelled ADRP oligonucleotides in the presence of purified PPAR $\alpha$ and/or purified RXR $\alpha$ proteins. Supershift experiment was carried out using anti-PPAR $\alpha$ antibody. Unlabelled oligonucleotides (ADRP or ADRP mut) were used at 10- or 100-fold molar excess to the labelled probe to perform competition assays. Closed and open arrowheads indicate the specific bands and the supershift band, respectively. (B) HepG2-tet-off-hPPAR $\alpha$ cells were treated with $100 \mu \mathrm{M}$ fenofibric acid for $8 \mathrm{~h}$ in the absence of Dox and processed for the ChIP assays. Soluble chromatin was immunoprecipitated with pre-immune rabbit IgG, anti$\operatorname{PPAR} \alpha$ antibody or anti-RXR $\alpha$ antibody. Immunoprecipitates were subjected to PCR with a primer-pair specific to the ADRP promoter. PCR was performed with total chromatin input.
定し, いずれの PPAR サブタイプも $\mathrm{RXR} \alpha$ と 2 量 体を形成してこの領域に結合し，転写を制御してい ることを明らかにした. ${ }^{16)}$

\section{6. おわりに}

近年，核内受容体の転写制御には，コアクチベー ターやコリプレッサーなどの転写共役因子の重要性 が唱えられている。転写共役因子の組織特異的な発 現が，核内受容体リガンドの組織特異的なアゴニス ト，アンタゴニストとしての作用を担っていると考 えられている。このような組織特異的な PPARの 活性調節薬（selective PPAR modulator; SPPARM） と PPAR，転写共役因子との相互作用は，高脂血 症，糖疗病，肥満など生活習慣病を標的とした薬剤 開発の観点からも非常に重要である. 17,25,26) これら SPPARM による転写制御機構を解明する 1 つの方 法として，筆者らが樹立したヒト肝癌由来 PPAR 発現細胞株と, 他の組織由来の PPAR 発現細胞株 を樹立して，PPARを中心とした複合体を比較・ 解析することが考えられる。一方で，PPARには ヒトとげっ歯類でその作用に種差が現れることが知

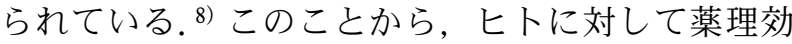
果を発揮する SPPARM を探索するためには，ヒ卜 の細胞を用いることが重要である。すなわち，今回 筆者らが樹立した細胞株とレポーターアッセイを組 み合わせることで，新たな SPPARM のスクリーニ ング系を構築することも可能であると考えられる.

本稿で概説した以外にも，筆者らは樹立した細胞 株を用いて新たな PPAR 標的遺伝子の同定を行つ ている（投稿準備中）。また，他の核内受容体であ る liver X receptor $\alpha(\mathrm{LXR} \alpha)$ を発現する細胞株を 樹立し， LXR $\alpha$ の新たな標的遺伝子の同定にも成功 している. ${ }^{27)}$ 今後, これら核内受容体の発現量が調 節可能なヒト細胞株を用いることで，核内受容体の さらなる機能の解明や新たな医薬品の開発を行いた い.

謝辞 本研究は, 大阪大学大学院薬学研究科蛋 白情報解析学分野で行われた研究であり, 終始, 御 指導，御鞭撻を賜りました土井健史教授に心から感 謝申し上げます。また，本研究を行うに当たり，御 協力と御助言を賜りました同研究室の皆様に心より 御礼申し上げます。本研究を推進するに当たり，幾 多の御協力と有益な御助言を賜りました東京大学先 
端科学技術研究センター システム生物医学ラボラ トリー 児玉龍彦教授, 浜窪隆雄教授, 酒井寿郎教 授，田中十志也准教授に深謝致します.

\section{REFERENCES}

1) Desvergne B., Wahli W., Endocr. Rev., 20, 649-688 (1999).

2) Mandard S., Muller M., Kersten S., Cell. Mol. Life Sci., 61, 393-416 (2004).

3) Lehrke M., Lazar M. A., Cell, 123, 993-999 (2005)

4) Yu S., Matsusue K., Kashireddy P., Cao W. Q., Yeldandi V., Yeldandi A.V., Rao M. S., Gonzalez F. J., Reddy J. K., J. Biol. Chem., 278, 498-505 (2003).

5) Matsusue K., Haluzik M., Lambert G., Yim S. H., Gavrilova O., Ward J. M., Brewer Jr. B., Reitman M. L., Gonzalez F. J., J. Clin. Invest., 111, 737-747 (2003).

6) Takahashi S., Tanaka T., Kodama T., Sakai J., Pharmacol. Res., 53, 501-507 (2006).

7) Tan N. S., Michalik L., Noy N., Yasmin R., Pacot C., Heim M., Fluhmann B., Desvergne B., Wahli W., Genes Dev., 15, 3263-3277 (2001)

8) Holden P. R., Tugwood J. D., J. Mol. Endocrinol., 22, 1-8 (1999).

9) Escher P., Wahli W., Mutat. Res., 448, 121138 (2000).

10) Nolte R. T., Wisely G. B., Westin S., Cobb J. E., Lambert M. H., Kurokawa R., Rosenfeld M. G., Willson T. M., Glass C. K., Milburn M. V., Nature, 395, 137-143 (1998).

11) Tanaka T., Yamamoto J., Iwasaki S., Asaba H., Hamura H., Ikeda Y., Watanabe M., Magoori K., Ioka R. X., Tachibana K., Watanabe Y., Uchiyama Y., Sumi K., Iguchi H., Ito S., Doi T., Hamakubo T., Naito M., Auwerx J., Yanagisawa M., Kodama T., Sakai J., Proc. Natl. Acad. Sci. U. S. A., 100, 15924-15929 (2003).

12) Glass C. K., Rosenfeld M. G., Genes Dev., 14, 121-141 (2000).

13) Robyr D., Wolffe A. P., Wahli W., Mol. Endocrinol., 14, 329-347 (2000).

14) Diradourian C., Girard J., Pegorier J. P.,
Biochimie, 87, 33-38 (2005).

15) Gelman L., Michalik L., Desvergne B., Wahli W., Curr. Opin. Cell Biol., 17, 216-222 (2005)

16) Tachibana K., Kobayashi Y., Tanaka T., Tagami M., Sugiyama A., Katayama T., Ueda C., Yamasaki D., Ishimoto K., Sumitomo M., Uchiyama Y., Kohro T., Sakai J., Hamakubo T., Kodama T., Doi T., Nucl. Recept., 3, 3 (2005)

17) Smith C. L., O’Malley B. W., Endocr. Rev., 25, 45-71 (2004).

18) Rodriguez J. C., Gil-Gomez G., Hegardt F. G., Haro D., J. Biol. Chem., 269, 1876718772 (1994).

19) Vu-Dac N., Chopin-Delannoy S., Gervois P., Bonnelye E., Martin G., Fruchart J. C., Laudet V., Staels B., J. Biol. Chem., 273, 25713-25720 (1998)

20) Krogsdam A. M., Nielsen C. A., Neve S., Holst D., Helledie T., Thomsen B., Bendixen C., Mandrup S., Kristiansen K., Biochem. J., 363, 157-165 (2002).

21) Shi Y., Hon M., Evans R. M., Proc. Natl. Acad. Sci. U.S.A., 99, 2613-2618 (2002).

22) Xu H. E., Lambert M. H., Montana V. G., Plunket K. D., Moore L. B., Collins J. L., Oplinger J. A., Kliewer S. A., Gampe Jr. R. T., McKee D. D., Moore J. T., Willson T. M., Proc. Natl. Acad. Sci. U.S.A., 98, 1391913924 (2001).

23) Brasaemle D. L., Barber T., Wolins N. E., Serrero G., Blanchette-Mackie E.J., Londos C., J. Lipid Res., 38, 2249-2263 (1997).

24) Chawla A., Lee C. H., Barak Y., He W., Rosenfeld J., Liao D., Han J., Kang H., Evans R. M., Proc. Natl. Acad. Sci. U.S.A., 100, 1268-1273 (2003).

25) Olefsky J. M., J. Clin. Invest., 106, 467-472 (2000) .

26) Sporn M. B., Suh N., Mangelsdorf D. J., Trends Mol. Med., 7, 395-400 (2001).

27) Ishimoto K., Tachibana K., Sumitomo M., Omote S., Hanano I., Yamasaki D., Watanabe Y., Tanaka T., Hamakubo T., Sakai J., Kodama T., Doi T., FEBS Lett., 580, 4929-4933 (2006). 